\title{
A comparative study of three commonly used fixation techniques for isolated medial malleolus fracture
}

\author{
İole medial malleol kııı̆ında sıkça kullanılan farklı üç tespit yönteminin karşılaştırma çalışması
}

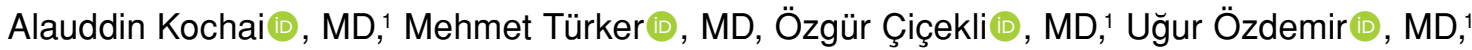 \\ Levent Bayram (D), MD, ${ }^{1}$ Ünal Erkorkmaz (D), MD, ${ }^{2}$ Erhan Şükür®D, MD ${ }^{1}$ \\ 1Department of Orthopedics and Traumatology, Sakarya University Training and Research Hospital, Sakarya, Turkey \\ ${ }^{2}$ Department of Biostatistics, Sakarya University Faculty of Medicine, Sakarya, Turkey
}

\begin{abstract}
Objectives: This study aims to compare the three most commonly used fixation techniques: tension-band wire fixation, partially threaded cannulated screws, and fully threaded cannulated headless compression screws.

Patients and methods: Ninety patients with medial malleolus fractures were included in the study. Patients were divided into three groups. Group A included patients who underwent tension-band wire fixation $(n=26)$, Group B partially threaded cannulated compression screws $(n=32)$, and Group C fully threaded cannulated headless compression screws $(n=32)$. The type of medial malleolus fracture, healing rates, implant-related complications, rate of infection, hardware removal, weight-bearing restrictions, mean interval time from the injury to the surgery, and Body Mass Indexes (BMIs) were investigated. The patients' radiographs (standard anteroposterior, lateral, and mortise) were reviewed. The American Orthopedic Foot and Ankle Society (AOFAS) scoring system was used for clinical evaluation.

Results: No significant difference was observed between the three groups in terms of age, gender, BMI, follow-up period, and fracture type. Union rate for group $\mathrm{C}$ was significantly shorter than groups A and $\mathrm{B}$. There was no implant failure or irritation in group $\mathrm{C}$ and this was statistically significant comparing to group $\mathrm{A}$ and $\mathrm{B}(\mathrm{p}=0.037)$. However, there was no significant difference between group A and $B(p=0.41)$. There were no significant differences in the three groups according to AOFAS. Patients with low BMI in groups A and B had a high rate of implant-related complications. There was a significant correlation between low BMI and implant-related complication $(\mathrm{p}<0.001)$.

Conclusion: Union rate in the group who were operated with fully threaded cannulated headless compression screws was significantly shorter than the other groups. This study has shown that tension band wiring and partially threaded cannulated compression screws can cause irritation of soft tissues and pain over the hardware implantation site. Patients with low BMI are vulnerable for implant-related complications.

Keywords: Ankle fracture; body mass index; headless cannulated compression screws; medial malleolus fracture; partially threaded cannulated compression screws; tension band wiring.
\end{abstract}

ÖZ

Amaç: $\mathrm{Bu}$ çalışmada medial malleol kırıklarında en çok kullanılan üç farklı tespit yöntemi olan gergi bandı tekniği, kısmi yivli kanüllü kompresyon vida ve tam yivli başsız kanüllü kompresyon vida yöntemleri karşılaştırıldı.

Hastalar ve yöntemler: Çalışmaya medial malleol kırığı olan 90 hasta dahil edildi. Hastalar üç gruba ayrıldı. Grup A gergi bandı ile ameliyat edilen hastalar $(n=26)$, grup B kısmen yivli kanüllü kompresyon vidalar $(n=32)$ ve grup $C$ başsız kanüllü kompresyon vidalar ile ameliyat edilen hastalar $(n=32)$ olarak ayrıldı. Kırığın tipi, iyileşme oranları, implanta bağlı komplikasyonlar, enfeksiyon oran1, implant tahliyesi, yükten kisitlamaları, yaralanmadan cerrahiye kadar olan süre ve hastaların vücut kütle indeksleri (VKİ) araştırıldı. Hastaların standart ön-arka, yan ve Mortis grafileri incelendi. AOFAS (American Orthopedic Foot and Ankle Society) skorlama sistemi klinik değerlendirme için kullanıldı.

Bulgular: Üç grup arasında yaş, cinsiyet, VKİ, izleme periyodu ve kırık tipi açısından anlamlı bir fark gözlenmedi. Kaynama süresi grup C'de grup A ve B'ye oranla anlamlı olarak daha kısa idi. Grup C hastalarında implant başarısızlığı veya irritasyonu görülmedi ve bu durum grup A ve B ile kiyaslayınca istatistiksel olarak anlamlı idi $(\mathrm{p}=0.037)$. Ancak bu konuda, grup A ve grup B arasında anlamlı bir fark yoktu $(\mathrm{p}=0.41)$. AOFAS skorlamasına göre üç grup arasında anlamlı bir fark görülmedi. A ve B grubunda VKİ'si düşük olan hastalarda yüksek oranda implanta bağlı komplikasyon görüldü. Düşük VKİ ile implanta bağlı komplikasyon oranı arasında anlamlı ilişki bulundu $(\mathrm{p}<0.001)$.

Sonuç: Kaynama süresinin tam yivli başsız kanüllü kompresyon vidası ile ameliyat edilen grupta diğer gruplara oranla anlamlı olarak daha kısa olduğu görüldü. $\mathrm{Bu}$ çalışma, gergi bandı yöntemi ve kısmi yivli kanüllü kompresyon vida ile medial malleol fiksasyonu yumuşak doku irritasyonuna ve implant bölgesinde ağrıya neden olabileceğini göstermiştir. Düşük VKI'si olan hastalar implanta bağlı komplikasyonlara daha açıktır. Anahtar sözcükler: Ayak bileği kırığı; vücut kütle indeksi; başsız kanüllü kompresyon vidası; medial malleol kırığı; kısmı yivli kanüllü kompresyon vidası; gergi bandi.

Received: May 21, 2018 Accepted: May 31, 2018

Correspondence: Alauddin Kochai, MD. Sakarya Üniversitesi Eğitim ve Araştırma Hastanesi Ortopedi ve Travmatoloji Kliniği, 54100 Erenler, Sakarya, Turkey. Tel: +90532 - 3275562 e-mail: alkoc79@gmail.com 
Intraarticular fractures necessitate accurate reduction and stable internal fixation as a general principle and medial malleolar fractures are not an exception. Failure to accurately reduce malleolar fractures may lead to post-traumatic pain in the joint, restricted range of motion (ROM), osteoarthritis, or a combination of complications. A thorough understanding of the ankle anatomy, mechanism of injury, interpretation of radiography, and adherence to basic principles of fracture management are the basis for optimum results. Open reduction and internal fixation (ORIF) can be considered the standard approach for treating unstable and displaced medial malleolar fractures. ${ }^{[1,2]}$ Many fixation methods have been described, including Kirschner wire, suture anchors, intraosseous wire loop fixation, antiglide plating, fully threaded headless compression screws, partially threaded compression screws, and tension-bend wiring. ${ }^{[3-8]}$ In the current study, we compared three different fixation techniques for medial malleolus fractures. To our knowledge, there is no such study so far comparing the three most commonly used fixation techniques: tensionband wire fixation, partially threaded cannulated compression screws, and fully threaded cannulated headless compression screws.

\section{PATIENTS AND METHODS}

We retrospectively investigated 250 patients who had medial malleolar fractures with or without lateral malleolar involvement and operated at a university hospital in the time period between January 2006 and December 2016. The patients who were included in the study had underwent one of the three surgical treatments: tension-band wire fixation (Group A), partially threaded cannulated compression screws (Group B), or fully threaded cannulated headless compression screws (Group C) for treatment of their medial malleolar fractures. A written informed consent was obtained from each patient. The study was conducted in accordance with the principles of the Declaration of Helsinki.

Exclusion criteria for the study were open fractures, individuals younger than 20 or older than 70 years of age, incomplete follow-up, incomplete data, pathological fracture, previous fracture treatment to the ipsilateral lower extremity or multitrauma, and patients with diabetes mellitus. All of the medial malleolus fractures were classified as either type $B$ or $C$ under the Herscovici system utilizing anteroposterior radiographs. ${ }^{[9]}$ We excluded type D and type $\mathrm{A}$ fractures because these fractures require screws to be inserted horizontally and are difficult to fix with retrograde screws. ${ }^{[10]}$ The type of medial malleolus fracture, healing rates, implant-related complications, rate of infection, rate of hardware removal, weight-bearing restrictions, mean interval time from the injury to the surgery, and Body Mass Indexes (BMIs) were investigated. Body Mass Index was calculated for each patient before surgery using the formula of dividing a person's weight in kilograms by the square of their height in meters $\left(\mathrm{kg} / \mathrm{m}^{2}\right)$.

The radiographs (standard anteroposterior [AP], lateral, and mortise views) were reviewed to identify the fracture pattern and the same views were also used in the follow-up clinics at two weeks, four weeks, six weeks, eight weeks, 10 weeks, and 12 weeks after surgery, to evaluate bone healing as part of hospital ankle fracture protocol. The decisions made for radiographic evaluation were based on radiological union, disappearance of the fracture line, and appearance of a bridging callus. The American Orthopedic Foot and Ankle Society (AOFAS) scoring system was used for clinical evaluation.

\section{Statistical analysis}

The VassarStats online statistical program was used for statistical analysis (Lowry, 2018). One-way ANOVA test was used to compare parametric data of the three groups, and Kruskal-Wallis and MannWhitney U test were used for non-parametrical data. $\mathrm{P}<0.05$ was considered statistically significant.

\section{RESULTS}

After excluding the patients according to the exclusion criteria, 90 patients with medial malleolus fractures, who were operated between January 2006 and December 2016, were included in the study. The patients were divided into three groups: Group A included 26 patients treated with tension-bend wiring; group B included 32 patients with partially threaded cannulated compression screws; and group $C$ included 32 patients with fully threaded headless cannulated compression screws.

The demographic data, mean interval time to surgery, BMI, follow-up period, and fracture types are provided in Table I. There was no significant difference between the three groups in terms of age, gender, BMI, follow-up period, and fracture type.

Union rate: Stable fixation and anatomic reduction were seen in all patients in early postoperative radiography. In the follow-up radiographs, no reduction or fixation loss was seen in any patient. The mean time for radiologic bone union was 10 weeks (8-12 weeks) in group A, 12 weeks (10-14 weeks) in group B, and nine weeks (8-10 weeks) in group C. There was no malunion or nonunion in any patients. 
TABLE I

Demographic data, mean interval time from injury to surgery, Body Mass Index, follow-up period and fracture types according to the groups (A, B and C)

\begin{tabular}{|c|c|c|c|c|c|c|c|c|c|c|c|c|}
\hline & \multicolumn{4}{|c|}{ Groups A } & \multicolumn{4}{|c|}{ Groups B } & \multicolumn{4}{|c|}{ Groups C } \\
\hline & $\mathrm{n}$ & Median & Min-Max & Mean & $\mathrm{n}$ & Median & Min-Max & Mean & $\mathrm{n}$ & Median & Min-Max & Mean \\
\hline Age (year) & & 38.23 & $21-55$ & & & 36.84 & $22-58$ & & & 37.75 & $21-60$ & \\
\hline $\begin{array}{l}\text { Sex } \\
\text { Female } \\
\text { Male }\end{array}$ & $\begin{array}{c}7 \\
15\end{array}$ & & & & $\begin{array}{c}9 \\
23\end{array}$ & & & & $\begin{array}{c}8 \\
24\end{array}$ & & & \\
\hline $\begin{array}{l}\text { Mean interval } \\
\text { from injury to } \\
\text { surgery (day) }\end{array}$ & & 2.88 & $0-5$ & & & 2.90 & $0-5$ & & & 3 & $0-4$ & \\
\hline Side & & & & & & & & & & & & \\
\hline $\mathrm{R}$ & 12 & & & & 16 & & & & 17 & & & \\
\hline L & 14 & & & & 16 & & & & 15 & & & \\
\hline Body Mass Index & & & & 23.04 & & & & 22.88 & & & & 24.34 \\
\hline Follow-up (month) & & 67 & $12-120$ & & & 58 & $12-120$ & & & 55 & $12-120$ & \\
\hline $\begin{array}{l}\text { Fracture type } \\
\text { B } \\
\text { C }\end{array}$ & $\begin{array}{l}14 \\
12\end{array}$ & & & & $\begin{array}{l}14 \\
18\end{array}$ & & & & $\begin{array}{l}17 \\
15\end{array}$ & & & \\
\hline$P$ values & & & & & & & & & & & & \\
\hline
\end{tabular}

Min: Minimum; Max: Maximum.

There was a significant difference between all three groups in terms of healing rate $(\mathrm{p}<0.0001$, Table II). Also, Tukey test showed a significant difference between each group (between group A and B: $p<0.01$; between group $A$ and $C$ : $p<0.01$; and between group $B$ and $C: p<0.01)$, therefore, union rate for group $C$ was significantly shorter than group $A$ and $B$, and for group $\mathrm{A}$, it was shorter than $\mathrm{B}$ (union rate: group $\mathrm{C}$ $<$ group A $<$ group B).

Implant related complications: Two patients in group A had Kischner migration without any fixation failure, and six patients had skin irritation and medial malleolar pain (over implants) again without any implant or reduction failure. Kirschners and the wires were removed due to skin irritation over the medial malleolus. They had difficulty wearing shoes. The BMIs of these patients were lower. One patient in group B had a screw pull-out without any reduction loss, and 10 patients had skin irritation and pain over the medial malleolus without any implant or reduction failure. Similarly, the screws were removed in these patients due to skin irritation, pain at the top of the screw, and difficulty wearing shoes. There was no implant failure or irritation in group C. There was a significant difference across the three groups $(p=0.037)$. However, there was no significant difference between group A and B ( $p=0.41)$. All of these patients with implant related complications needed a second surgery for implant removal (Table II, Table III). The implants were removed eight months after initial surgery in four patients, nine months in one patient, 12 months in eight patients, 15 months in one patient, 18 months in two patients, and 24 months in three patients.

Infection: None of the patients in groups B and C had infections. One patient in group A developed cellulitis after implant removal. This was successfully treated with oral antibiotics.

\section{TABLE II}

AOFAS scoring system was used for clinical evaluation, healing rate (or union period), implant related complications, implant removal for all three groups (A, B and $C)$, and $p$ values

\begin{tabular}{|c|c|c|c|c|c|c|c|c|}
\hline \multirow[b]{2}{*}{ Groups } & \multicolumn{2}{|c|}{ AOFAS } & \multicolumn{2}{|c|}{$\begin{array}{l}\text { Healing rate } \\
\text { (week) }\end{array}$} & \multicolumn{2}{|c|}{$\begin{array}{l}\text { Implant related } \\
\text { complication }\end{array}$} & \multicolumn{2}{|c|}{ Implant removal } \\
\hline & Median & Min-Max & Median & Min-Max & $\mathrm{n}$ & $\%$ & $\mathrm{n}$ & $\%$ \\
\hline$A$ & 85.57 & $70-95$ & 10 & $8-12$ & 8 & 30 & 8 & 30 \\
\hline $\mathrm{B}$ & 85.62 & $75-90$ & 12 & $10-14$ & 11 & 34 & 11 & 34 \\
\hline $\mathrm{C}$ & 86.40 & $75-95$ & 9 & $8-10$ & 0 & 0 & 0 & 0 \\
\hline$P$ values & \multicolumn{2}{|c|}{0.73} & \multicolumn{2}{|c|}{$<0.0001$} & \multicolumn{2}{|c|}{0.037} & \multicolumn{2}{|c|}{0.037} \\
\hline
\end{tabular}


TABLE III

Body Mass Index values and implant related complications the group A, B and C for each age category

\begin{tabular}{lcccc}
\hline Body Mass Index & Group A & Group B & Group C & Implant related complication \\
\hline$<18.5$ & 10 & 6 & 8 & 14 \\
$18.5-25$ & 4 & 8 & 10 & 1 \\
$25-30$ & 10 & 12 & 8 & 2 \\
$>30$ & 2 & 6 & 6 & 2 \\
Total & 26 & 32 & 32 & 19 \\
\hline
\end{tabular}

Restriction of weight-bearing and cast removal: Posterior splints were removed four weeks after surgery in all groups and partial weight-bearing started at six weeks after surgery. Range of motion exercise for the ankle joint started after posterior splint removal. Full weight-bearing was allowed after 10 weeks in all groups. There were no significant differences in the three groups in terms of restrictions on weight-bearing activities or cast removal. None of the patients in any of the groups developed Sudeck atrophy.

Mean interval time between injury and surgery: The mean interval from injury to the surgery was 2.88 (range 0-5) days for Group A, 2.9 (range 0-5) days for group $B$, and 3 (range 0-4) days for group C, with no significant differences between the three groups (Table I).

Arthrosis: Arthrosis in the joint line was not observed in any of the patients preoperatively or during the follow-up period.

AOFAS scores for clinical evaluation were provided in Table II: Group A; good outcomes were obtained in 16 patients, excellent outcomes in eight patients, and two patients had a AOFAS score of 70. For Group B; good outcomes were obtained in 19 patients, excellent outcomes in 10 patients, and three patients had an AOFAS score of 75. In Group C; good outcomes were obtained in 20 patients, excellent outcomes in 10 patients, and two patients had an AOFAS score of 75 . There were no significant differences between the three groups.

Body Mass Index values for all three groups were shown in more details on the Table III: Patients with low BMI in groups A and B had high rates of implant-related complications. There was a significant correlation between low BMI and implant-related complication $(p<0.0001)$. This could be due to less subcutaneous soft tissue volume, which makes the patients with low BMI more vulnerable to skin irritations caused by implants. In group $C$, there was no correlation between BMI and implant-related complications (Table III).

\section{DISCUSSION}

Ankle fractures are the most common fractures treated by orthopedic surgeons. The current standard treatment for medial malleoli fractures is ORIF. Several studies have indicated that internal fixation of displaced malleolar fractures of the ankle provides better results. ${ }^{[11-13]}$ The treatment of malleolar fractures with accurate open reduction and stable internal fixation using the $\mathrm{AO}$ method and principles produced a higher percentage of excellent and good results. ${ }^{[14]}$ The current study supports these statements. Different methods and implants have been described in the literature. These include cancellous screws (unicortical or bicortical), solid cortical screws, headless compression screws, staples, and tension band wiring. ${ }^{[14-18]}$ There is no adequate evidence to state one method is superior over any other, and implant-related pain is a significant factor requiring hardware removal in approximately 13 to $17 \%$ of patients. ${ }^{[19-21]}$ In the current study, we aimed to compare the three most popular surgical techniques for medial malleolus fractures. Our results showed $30 \%$ and $34 \%$ hardware removal for group A and B, respectively, but no removal was reported for group C (Table II).

In this study, the AOFAS scoring system was used for clinical evaluation. According to AOFAS, the current study showed good and excellent results for all three groups (A, B, C, scoring 92.3\%, 90.62\%, and $93.75 \%$, respectively. These figures are similar to the reported results in the literature. Sang-Hanko and Young-Junpark, ${ }^{[21]}$ achieved excellent and good results in $78 \%$ of cases treated with malleolar screws and $89 \%$ of cases treated with tension-band wiring. Barnes et al. $^{[14]}$ reported a satisfactory functional outcome with high rates of union with headless compression screws. Li et al., ${ }^{[22]}$ who performed a minimally invasive surgery for medial malleolus fracture, also reported good and excellent results in $91.6 \%$ of patients. The high rate of AOFAS in our study could be due to isolated medial fracture, early treatment, no comorbidities, anatomic reduction and rigid fixation, and close fractures (Table II). 
In the literature, the mean time for radiologic bone union was reported to be between 8 and 12 weeks. Alam and Parviz ${ }^{[23]}$ reported a mean time of 12 weeks for malleolar screws and nine weeks for tension-band wiring. The results from Öçgüder et al.'s study, ${ }^{[8]}$ who compared tension band wiring and screw fixation, were similar. $\mathrm{Li}$ et al. ${ }^{[22]}$ performed a minimally invasive surgery for medial malleolus fractures and reported a fracture healing time ranging from 8 to 12 weeks, with an mean $11.8 \pm 0.9$ weeks for the minimally invasive group; and a fracture healing time mean of 15.9 in the control group. Tekin et al., ${ }^{[2]}$ who fixed medial malleolus fractures with headless compression retrograde screws, reported similar results to ours. In the current study, the mean time for radiologic bone union was between 9 and 12 weeks. On the other hand, this study showed statistically significant differences in radiologic bone union time between the groups (A, B, and C), group C (headless compression screws) being the shortest.

We did not observe nonunion or delayed union in our study, which was similar to the study of Barnes et al., ${ }^{[14]}$ who fixed medial malleolus fractures with headless compression screws. Öçgüder et al., ${ }^{[8]}$ reported only one delayed union out of 20 patients who were operated with malleolar screws and $100 \%$ union in the patients operated with tension band wiring. Again, Alam and Parviz ${ }^{[23]}$ achieved 100\% union rate in both screw fixation and tension band wiring groups without any case of delayed union. As Öçgüder et al., ${ }^{[8]}$ reported, the high incidence of union and low incidence of non-union in our study might be attributed to stable anatomic reduction, limited soft tissue stripping, and exclusion of open fractures. We also believe that the high rate of achieving good and excellent clinical results and $100 \%$ union rate in the current study might be due to exclusion of multi-trauma patients and open fractures, which may adversely affect the outcome, thoroughly applying fracture management principles and paying more attention to anatomic reduction and stable fixation of the fractures, and having more experienced surgeons in a major trauma center in the region.

Weight-bearing following the surgery is another well-documented issue in the literature; Ayyuob et al. ${ }^{[8]}$ restricted weight-bearing activity to six weeks. They also kept the joint splinted for six weeks and after splint removal, they initiated only partial weight-bearing activity. They started full weightbearing activity after 12 weeks. Tekin et al., ${ }^{[2]}$ allowed partial weight-bearing activity after eight weeks. They began full weight-bearing movement after 10 weeks. They removed the split cast during the second week following soft tissue healing and then, commenced knee and ankle exercises. Li et al. ${ }^{[22]}$ started limb muscle isometric exercise on the second day after surgery, and ankle joint functional exercise started on the third day. One week after surgery, they allowed the patient to get out of bed and perform non-weight-bearing activities. After 3-4 weeks, they allowed partial weight-bearing movement. Once the radiographs confirmed union of the fracture, the patients were allowed to start full weight-bearing when walking. They did not perform a splint cast after surgery. In the current study, the standard was to remove the cast after four weeks, followed by knee and ankle exercise, partial weight-bearing after six weeks, and full weight-bearing after 10 weeks in all three groups.

The lack of the soft tissue enveloped around bony prominences increases implant-related problems after ankle fracture fixation. This may affect functional outcomes and may require a second surgery for revision or implant removal. ${ }^{[20,21]}$ Implant-related complications was one of the main differences among three groups. In group A, 8 of 26 patients $(30 \%)$ and in group B 10 of $32(31.25 \%)$ patients had implant-related problems, and they all underwent a second surgical procedure for implant removal. However, in group C, there were no implant-related complications. In statistical analysis, this proved to be a significant difference $(\mathrm{p}=0.037)$. In group $\mathrm{A}$, the patients who had implant-related complications had an mean BMI of 19 (16.5-20). Similarly, in group B, the patients who had implant-related complications had an mean BMI of 18 (16.5-20). There were no significant differences in terms of BMI across the three groups. By comparison, Ostrum and Litsky ${ }^{[15]}$ reported a $15 \%$ rate of implant-related complications, and Georgiadis and White ${ }^{[25]}$ reported rate of $13.6 \%$ for implant-related complications. Barnes et al. ${ }^{[14]}$ reported that none of the patients with headless compression screws required hardware removal from the screw prominence. Tekin et al. ${ }^{[24]}$ also reported no implant-related complications with headless compression screws. In our study, the high rate of implant-related complications could be due to low BMI of the patients, as there was a significant correlation between low BMI and implantrelated complications $(\mathrm{p}<.0001)$, in regard to less subcutaneous soft tissue volume over the medial malleolus, which may make the patients with low BMI more vulnerable to skin irritations and pain caused by implants.

\section{Limitation}

A larger number of cases is needed to identify the precise relationship between BMI and implant 
complication. Small sample sizes are also a limitation for comparing the three different surgical techniques.

\section{Conclusion}

The present study has shown that patients with medial malleolar fracture who underwent treatment with tension band wiring, partially threaded cannulated compression screws, and fully threaded cannulated headless compression screws showed good to excellent functional outcomes. Union rate in the group treated with fully threaded cannulated headless compression screws was significantly shorter than in the other groups. Tension band wiring and partially threaded cannulated compression screws can cause irritation of soft tissues and pain over the hardware implantation site. Patients with low BMI are vulnerable to implant-related complications. Therefore, we advise that practitioners use headless cannulated compression screws in patients with low BMI to prevent implant irritation.

\section{Declaration of conflicting interests}

The authors declared no conflicts of interest with respect to the authorship and/or publication of this article.

\section{Funding}

The authors received no financial support for the research and/or authorship of this article.

\section{REFERENCES}

1. Yablon IG, Heller FG, Shouse L. The key role of the lateral malleolus in displaced fractures of the ankle. J Bone Joint Surg [Am] 1977;59:169-73.

2. Vander Griend R, Michelson JD, Bone LB. Instructional course lecture: fractures of the ankle and the distal part of the tibia. J Bone Joint Surg [Am] 1996;78:1772-83.

3. Koslowsky TC, Mader K, Kirchner S, Gausepohl T, Pennig D. Treatment of medial malleolar fractures using finethreaded K-wires: a new operative technique. J Trauma 2007;62:258-61.

4. Loveday DT, Arthur A, Tytherleigh-Strong GM. Technical tip: fixation of medial malleolar fractures using a suture anchor. Foot Ankle Int 2009;30:68-9.

5. Torppi P. Osteosynthesis of the medial malleolus by using a loop of steel wire. Ann Chir Gynaecol Fenn Suppl 1954;43:450-9.

6. Schatzker J, Albo A, Sheehan J. Screws and plates and their application. In: Allgower M, editor. Manualof Internal Fixation. New York: Springer Verlag; 1991. p. 179-290.

7. Kupcha P, Pappas S. Medial malleolar fixation with a bicortical screw: technique tip. Foot Ankle Int 2008;29:1151-3.
8. Öçgüder DA, Fırat A, Özdemir M, Tecimel O. Is the use of headless compression screws appropriate in arthroscopic ankle arthrodesis? Eklem Hastalik Cerrahisi 2017;28:171-6.

9. Pankovich AM. Acute indirect ankle injuries in the adult. 1981. J Orthop Trauma 2002;16:58-68.

10. Burwell HN, Charnley AD. The treatment of displaced fractures at the ankle by rigid internal fixation and early joint movement. J Bone Joint Surg [Br] 1965;47:634-60.

11. de Souza LJ, Gustilo RB, Meyer TJ. Results of operative treatment of displaced external rotation-abduction fractures of the ankle. J Bone Joint Surg [Am] 1985;67:1066-74.

12. Cimino W, Ichtertz D, Slabaugh P. Early mobilization of ankle fractures after open reduction and internal fixation. Clin Orthop Relat Res 1991;267:152-6.

13. Beris AE, Kabbani KT, Xenakis TA, Mitsionis G, Soucacos PK, Soucacos PN. Surgical treatment of malleolar fractures. A review of 144 patients. Clin Orthop Relat Res 1997;341:90-8.

14. Barnes H, Cannada LK, Watson JT. A clinical evaluation of alternative fixation techniques for medial malleolus fractures. Injury 2014;45:1365-7.

15. Ostrum RF, Litsky AS. Tension band fixation of medial malleolus fractures. J Orthop Trauma 1992;6:464-8.

16. Ricci WM, Tornetta P, Borrelli J Jr. Lag screw fixation of medial malleolar fractures: a biomechanical, radiographic, and clinical comparison of unicortical partially threaded lag screws and bicortical fully threaded lag screws. J Orthop Trauma 2012;26:602-6.

17. Schiedts D, Fleurat E, Bouger D, Bastaraud H. Osteosynthesis of internal malleolar fracture by staplers. Rev Chir Orthop Reparatrice Appar Mot 1997;83:70-3. [Abstract]

18. SooHoo NF, Krenek L, Eagan MJ, Gurbani B, Ko CY, Zingmond DS. Complication rates following open reduction and internal fixation of ankle fractures. J Bone Joint Surg [Am] 2009;91:1042-9.

19. Minkowitz RB, Bhadsavle S, Walsh M, Egol KA. Removal of painful orthopaedic implants after fracture union. J Bone Joint Surg [Am] 2007;89:1906-12.

20. Brown OL, Dirschl DR, Obremskey WT. Incidence of hardware-related pain and its effect on functional outcomes after open reduction and internal fixation of ankle fractures. J Orthop Trauma 2001;15:271-4.

21. Sang-Hanko M, Young-JunPark D. Comparison between screw fixation and tension-band wiring for medial malleolus fractures. Korean Soc Foot Surg 2002;6:41-4.

22. Li L, Huo Y, Yin Z, Yu J, Shen L, Wang T, et al. Minimally invasive treatment of medial malleolus fracture by implanting a hollow screw under C-arm X-ray. Int J Clin Exp Med 2016;9:5189-92.

23. Alam N, Parviz S. Comparative study of malleolar fractures by tension-band and malleolar screw. BOS J 2007;12:13-9.

24. Tekin AÇ, Çabuk H, Dedeoğlu SS, Saygılı MS, Adaş M, Büyükkurt CD, et al. Anterograde Headless Cannulated Screw Fixation in the Treatment of Medial Malleolar Fractures: Evaluation of a New Technique and Its Outcomes. Med Princ Pract 2016;25:429-34.

25. Georgiadis GM, White DB. Modified tension band wiring of medial malleolar ankle fractures. Foot Ankle Int 1995;16:64-8. 